\title{
Assessment of lives stock feed resources and its constraint in Farta woreda
}

\begin{abstract}
The study was conducted in Farta Woreda, South Gondar Zone of the Amhara National Regional State with the objective of assessing of major livestock feed resource and constraint in Farta Wereda. The study area was located between $11^{\circ} 51^{\prime} \mathrm{N}$ latitude \& $38^{\circ} 17^{\prime} \mathrm{E}$ longitude and found $666 \mathrm{~km}$ far from Addis Ababa \& $100 \mathrm{~km}$ from Bahir Dar. The most common feed resource in the study area was crop residues (Teff straw, wheat straw and barely straw was high supplied types of feed resources in the study areas about $86.6 \%, 76.7 \%$ and $66.6 \%$, respectively), native pasture and less amount of industrial by-product. Hay was the common and the only methods of feed preservation in the study area but none of them preserve their feed as form of silage due to lack of awareness. The three Kebeles (district) were selected by using purposive sampling methods due to transport facility and 30 households selected by randomly from the three kebele. We were developed structured and semi-structured questionnaire to collect the data on feed resource availability and constraint in the study area. The household population was found in Wawamegera, Abaregay and Tsegure kebeles which accounts $36.9 \%, 32.2 \%$ and $30.9 \%$, respectively. Cattle were the high populated animals in the study area that accounts $40 \%$ from the total livestock in the three Kebeles. Both grazing and feed supplementation feeding system was more practiced in all study areas which accounts $53.3 \%$ by followed zero grazing $16.7 \%$. Thus the mean average milk yields in the study area were $3.9 \mathrm{~kg} / \mathrm{day} 3.4 \mathrm{~kg} /$ day $\& 3.2 \mathrm{~kg}$ /day in Tsegur, Abaregay \& Wowamagera, respectively. This indicates Tsegure kebele was produced higher milk yield than the two kebeles.
\end{abstract}

Keywords: assessment, constraint, feed, resource, straw, industrial by product
Volume 6 Issue 3 - 2018

Lemma Gulilat, Yasin Temam, Tacher Haile, Tigereda Birhane

Department of Animal Science and Animal Nutritionist, Debre Tabor University, Ethiopia

Correspondence: Lemma Gulilat, Department of Animal Science and Animal Nutritionist, Faculty of agriculture and environmental science, Debre Tabor University, P.O.Box 272, Ethiopia, Email lemmagulilat2009@gmail.com

Received: November II, 2017 | Published:June 13, 2018

\section{Introduction}

In the world, forage grass is the main source of feed for most ruminant farm animals and it provide to animals mixed with most palatable high quality pasture and hay at low cost however, common grasses are capable of grazing by livestock and grow on a wide range of soil and climate. ${ }^{1}$ Animal production in extensive range land conditions in America, Australia and North Asia is almost entirely depend on the native grass land vegetation with animal often being export to other agro climate zone for fishing straw is a particular important feed resource in area of Asia and Africa with high human population pressure. ${ }^{2}$ According to Givens et al., ${ }^{2}$ the feed resource availability is affected by the season, which is more serious in dry season.

Ethiopia has large livestock resource in Africa, ${ }^{3}$ which are 29 million cattle, 24 million sheep, 18 million goats, 1 million camel, 7 million equines and 50million of poultry, distribute through the country and the greatest concentration occurs were $70 \%$ of human population live. ${ }^{4}$ In Amhara Regional State, the livestock population is estimated to be 11.76 million cattle, 9.47 million sheep, 5.47 million goat, 2.14 million equines, 0.047 million camel and 12.36 million poultry. ${ }^{5}$ These are shows that Farta Woreda had a great potential and contribution for cattle and poultry for the region. However, the productivity of livestock is extremely low interims milk, meat production and drought power output, ${ }^{6}$ mainly because of inadequate nutrition, unimproved generic resource and prevalence of diseases.

Feed shortage for both interims of quantity and quality is a major problem hindering the development of livestock development industry in Ethiopia the factor contribute this defect in dry matter (DM) supply are fast deterioration of natural grazing land associated with arise in crop cultivation, over stock and recurrent drought. The tendency of allocating natural grazing land for crop cultivation has been increasing to satisfy the grain production needs of rapidly increase human population. ${ }^{6}$

According to Alemayehu ${ }^{4}$ livestock feed resource are classified as natural pasture, crop residue, improved pasture, forage, agroindustrial by product, other by product like food and vegetable refusals are the largest feed type in Ethiopia. Under the condition that prevails in developing country poor quality feed (low digestibility and low nutritive value) is one of the major factors limiting livestock production. ${ }^{3}$ Therefore, this research showed as the severity of livestock feed resources in Farta districts and farmers privileges to minimize the problems to improve their animal's productivity.

\section{Objective of the Study}

To identify the major types of livestock feed resource in the Kebeles

To assess the constraints of feed resource in the Kebeles

\section{Materials and methods}

\section{Description of the study area}

The study was conducted in Farta Woreda in South Gondar Zone of Amhara Regional State. This Woreda is located b/n11 $51^{`} \mathbf{N}$ 
latitude and $38^{\circ} 17^{\prime} \mathrm{E}$ longitude. The climate condition of this Woreda is $44 \%$ moist Dega \& $56 \%$ Weina-Dega. The temperature is ranged from $9-25^{\circ} \mathrm{C}$ and the average annual rainfall is $1250 \mathrm{~mm}$. The altitude of this Woreda range from $1920 \mathrm{~m}$ to $4135 \mathrm{~m}$ above sea level and the total area of the land are 11788ha and from this 11567ha are used for grazing land. The total human population of the Woreda is 261,290 of which 135, 380 males \& 125,910 are females. ${ }^{7}$ The livestock population of the Woreda is estimated to be 168,307 cattle, 156,18 sheep, 40,163 goat, 29,017 equine and 89,496 poultry. ${ }^{7}$

\section{Sampling procedure \& sample size}

From Farta woreda three kebeles were selected for this study purposively based on settlement of farmers, involved in livestock rearing and accessibility of transport services, which are Abarage, tegur, and wowamagera. From the three kebele 10 house hold were selected randomly.

\section{Methods of study and data collection}

The primary data was collected through interview, focal group discussion, key informant discussion and physical observation. Agricultural office and development agent data also used as secondary data regarding to know the demographic information about the household. For this secondary data collection used structured and semi-structured questionnaire.

\section{Data analysis}

The collected data were analyzed by Excel, spps software and presented in the form of tables and each of the data was interpreted using descriptive statistical analysis such as mean, or average and percentage.

\section{Results and discussion}

\section{House hold characteristics}

As indicated in Table 1, the mean average age of respondents in three kebeles i.e. Abarragay, Tsegur and wowamagera was 48.5, 47.5 and 49.8 , respectively that nearly similar results that reported by Teshome $^{6}$ and Mesfin et al. ${ }^{8}$

\section{Gender distribution of households}

The high percentage of respondents was females that about $63.3 \%$ and the lowest was males $36.6 \%$ as indicted in Table 2 . It creates agreement that reported by Ahmed Hassen ${ }^{9}$ in bison Worland wired. Most of males are involving on farm activity but the females are homestead activities. Usually, in different area of the region there are small numbers of female households but in our survey area was the reverse. This is similar with the report of Teshome. ${ }^{6}$ This report also indicated that, females are engaged in different on farm and homestead activities like, preparing food, handling livestock and feeding them around home.

\section{Types of livestock}

From the predominant livestock species kept in the study area, the number of cattle is $(40 \%)$ higher than sheep $(27 \%)$, equine $(19 \%)$ and goat $(14 \%)$. This is due to Cattles are multipurpose animals, farmers used as drought powers, provide products milk and meat, wealth status, social heritages similar to that reported by Teshome. ${ }^{6}$ The large number of cattle was found in wowamagera. However, irrespective of their population the farmer's get fewer products from their animals.
This is due to feed shortage; low quality feeds crop residues and roughages as indicated in Table $3 \&$ Table 4.

\section{Major livestock feed resources}

According to this study common feed resource were crop residues like teff straw $86.6 \%$. This is agreed with results that reported by Mamo Mengesha. ${ }^{10}$ From 30 households 26 were used teff straw as feed for their livestock, which has low nutritive values less than animal requirements also it agree results that obtained by Ahmed Hassan. ${ }^{9}$ The low quality feed could affect intake of feed, digestibility and productivity of animals. From the total households $46.6 \%$ were supplements their animals by using agricultural by products. This indicates that, farmers in this area have trying to improve the animal productivity and their income.

\section{Feed treatments and types of grazing}

Feed nutritive value improvement techniques or Feed treatment and grazing practice is presented in Table 5 . In this study area farmers were not used feed treatment rather chopping and grinding. This finding was agrees with Lemma et al. ${ }^{11}$ However, about $16.6 \%$ of respondent used physical treatments (chopping) and about $10 \%$ of respondents were grinding. Regarding to feeding system/grazing practice/, 30\% of households were used free grazing without supplementation but $53.33 \%$ of the respondent was used both grazing and supplementation. At about $16.6 \%$ of households was used zero grazing in the study area in this case, some model farmers who have individual pastures land used this type of grazing by cutting and carry system that brought to defined place in appropriate manner, this opposes result that reported by Mamo. ${ }^{10}$

\section{Amount of milk products from lactating cows}

The amount of milk yields obtained per day was relatively low in the study area. As it indicates in Table 6 the mean average of milk in wowamagera was $3.2 \mathrm{~kg}$ that less than Tsegur and Abaragay 3.9 and $3.4 \mathrm{~kg}$ respectively. This opposes results reported by Getachew ${ }^{12}$ that he obtained the mean average of milk $5.2 \mathrm{~kg}, 6.1 \mathrm{~kg}$, and $4 \mathrm{~kg}$, for different peasant association. This is due to difference in using concentrate feeds or industrial by products like NSC, wheat bran etc, for lactating cows. ${ }^{13}$

Table I Households characteristics in three kebeles

\begin{tabular}{llll}
\hline \multirow{2}{*}{ Variables } & \multicolumn{2}{l}{ Households } & \multirow{2}{*}{ Mean/average } \\
\cline { 2 - 3 } Size of Age/ years/ & Maximum & Minimum & \\
Abaragay & 80 & 20 & 48.5 \\
Tsegur & 75 & 25 & 47.5 \\
W/magera & 85 & 18 & 49.8 \\
Family size(no) & & & \\
Abaragay & 10 & 3 & 5.2 \\
Tsegur & 10 & 2 & 5.4 \\
W/magera & 8 & 4 & 6.2 \\
\hline
\end{tabular}


Table 2 Number of male and female interviewed in three kebeles

\begin{tabular}{|c|c|c|c|c|c|}
\hline \multirow{2}{*}{$\begin{array}{l}\text { Sex dis- } \\
\text { tribution }\end{array}$} & \multicolumn{3}{|c|}{$\begin{array}{l}\text { Number household rear } \\
\text { livestock }\end{array}$} & \multirow{2}{*}{ Total } & \multirow{2}{*}{$\begin{array}{l}\text { Percentage } \\
\text { (\%) }\end{array}$} \\
\hline & Abaragay & Tsegur & $\begin{array}{l}\text { WI } \\
\text { magera }\end{array}$ & & \\
\hline $\begin{array}{l}\text { Number of } \\
\text { males }\end{array}$ & 3 & 4 & 4 & II & 36.66 \\
\hline $\begin{array}{l}\text { Number of } \\
\text { females }\end{array}$ & 7 & 6 & 6 & 19 & 63.34 \\
\hline Total & 10 & 10 & 10 & 30 & 100 \\
\hline
\end{tabular}

Table 3 Types of livestock in the kebeles

\begin{tabular}{llllll}
\hline \multirow{2}{*}{$\begin{array}{l}\text { Types of } \\
\text { livestock }\end{array}$} & \multicolumn{2}{l}{ No of livestock in the kebele } & Total & Percent \\
\cline { 2 - 4 } & Abaragay & Tsegur & W/magera & & \\
\hline Cattle & 68 & 50 & 67 & 185 & 40 \\
Sheep & 58 & 47 & 54 & 129 & 27 \\
Equine & 19 & 27 & 44 & 90 & 19 \\
Goat & 29 & 27 & 12 & 68 & 14 \\
Total & 142 & & 187 & 465 & 100 \\
\hline
\end{tabular}

Table 4 Major livestock feed resources in the kebeles

\begin{tabular}{llllll}
\hline $\begin{array}{l}\text { Types of } \\
\text { feeds }\end{array}$ & \multicolumn{3}{l}{ Household number } & Total & $\begin{array}{l}\text { Per } \\
\text { cent(\%) }\end{array}$ \\
\cline { 2 - 4 } & Abaragay & Tsegur & $\begin{array}{l}\text { WI } \\
\text { magera }\end{array}$ & & \\
\hline $\begin{array}{l}\text { Crop residues } \\
\text { Teff Straw }\end{array}$ & 8 & 9 & 9 & 29 & 86.6 \\
Wheat Straw & 7 & 8 & 8 & 23 & 76.66 \\
Barley Straw & 7 & 6 & 7 & 20 & 66.66 \\
Maize Stover & 5 & 4 & 3 & 12 & 40 \\
$\begin{array}{l}\text { Sorghum } \\
\text { Stover }\end{array}$ & 3 & 2 & 2 & 7 & 23.33 \\
$\begin{array}{l}\text { Industrial by } \\
\text { products }\end{array}$ & 5 & 5 & 4 & 14 & 46.6 \\
Green grass & 5 & 4 & 5 & 14 & 46.6 \\
Hay & 7 & 8 & 7 & 21 & 70 \\
\hline
\end{tabular}

Table 5 Feeding system/grazing practice/ in each kebeles

\begin{tabular}{llllll}
\hline \multirow{5}{*}{$\begin{array}{l}\text { Types of } \\
\text { treatments }\end{array}$} & \multicolumn{2}{l}{$\begin{array}{l}\text { Number of respondents in each } \\
\text { kebele }\end{array}$} & \multicolumn{2}{l}{ Total } & $\begin{array}{l}\text { Percent } \\
\text { (\%) }\end{array}$ \\
\cline { 2 - 4 } & Abaragay & Tsegur & $\begin{array}{l}\text { w/ } \\
\text { Magera }\end{array}$ & & \\
\hline $\begin{array}{l}\text { Feeding system in each kebele } \\
\text { Free grazing }\end{array}$ & 4 & 3 & 2 & 9 & 30 \\
Zero grazing & 2 & 1 & 1 & 5 & 16.66 \\
& & & & & \\
$\begin{array}{l}\text { supplement } \\
\text { and grazing }\end{array}$ & 6 & 5 & 5 & 16 & 53.33 \\
\hline
\end{tabular}

Table 6 Milk yield in three kebeles

\begin{tabular}{llll}
\hline \multirow{2}{*}{ Name of kebeles } & \multicolumn{3}{l}{ Milk yield in kg/day } \\
\cline { 2 - 4 } & Max & Min & Mean (average) \\
\hline Abarragay & 7 & 2 & 3.4 \\
Tsegur & 8 & 2 & 3.9 \\
w/magera & 6 & 1 & 3.2 \\
\hline
\end{tabular}

\section{Conclusions and recommendations}

The study was consisted to identifying the major types of feeds, grazing type, treatment method and amount of milk yield obtained per days by taking sample of 30 respondents in the study area. In our study area most of the respondent was female $63.34 \%$ and high number of family size was found in W/megera $36.9 \%$. In our study area cattle were more populated in each kebele it accounts $40 \%$ and few numbers of goats were found in each kebele. The survey result indicated that about $86.6 \%$ of respondents were used teff straw and about $76.6 \%$ and $66.6 \%$ of respondents used wheat and barley straw respectively, additionally about $70 \%$ respondents preserve feed used as a form of hay. About $46.6 \%$ of respondents were used industrial byproducts and native pasture for their livestock. This indicates that few numbers of farmers used such types of supplement feed to get enough amounts of animal product and by product. Additionally no one of the respondents were any chemical treatments neither urea nor ammonia in our study area. About $16.6 \%$ of respondents used zero grazing and treated by physical methods by chopping and $10 \%$ by grinding.

As result of feed shortage the amount of milk products is very low in the study area, in order to enhance the milk yield the smallholder farmer should practice treatment of low quality feeds, using supplement feed (NSC, wheat bran) and other available by products without fear the costs of concentrate feeds. Additionally the farmers should use appropriately their natural pasture without exposure of over grazing and other mechanical defects. Generally, the farmers, extension works, development organization as a whole should work together on protection of livestock feed resources deterioration. We have faced different challenges during our study like absences of references and lack financial support. We recommended for farther study about feed resource by considering representative samples in Farta Woreda.

\section{Acknowledgements}

Firstly, I am greatly indebted to Ministry of Education for sponsoring my graduate studies and the School of Animal and Range Sciences and School of Graduate Studies for academic and facility support. I am indebted to my advisors Dr. Mengstu Urge and Dr. Getachew Animut, to encouragement, insight, guidance, and professional expertise the completion of this Thesis work.

\section{Conflict of interest}

The author declares that there is no conflict of interest.

\section{References}

1. Getachewu Eshetie. An assessment of livestock production system on cross breed and influence of supplementation feeds on production. 2007.

2. Givens OIE, Owen E, Axford RFE, et al. Forage evaluation in Ruminant nutrition. AGRIS. 2000. 
3. FAO. Major livestock Feed resources in Ethiopia. 2014.

4. Alemayehu Mengistu. Forage production in Ethiopia: A case of study with emphasis for live stock production. Ethiopia; 2002.

5. CSA. Central statistics Authority of Federal Demographic Republic of Ethiopia. Agricultural sample survey; 2008.

6. Teshome Derso. On farm evaluation of urea treated rice bran supplementation on feed intake, milk yield \& composition of Fogera crow's north western Ethiopia. 2009. p. 1-89.

7. Farta Worda Agricultural office. Annual statistical data of planning and monitoring team. Debre Tabor Town, Farta; 2006.

8. Mesfin D, Seyoum B, Aemiro K, et al. On farm excavation of locating of cross bred(bostaurwxbosindicus) dairy cows fed a basal diet of urea treated teff straw supplemented with scop protein source during the dry season in crop livestock production system of north shoa. Ethiopia; 2009.

9. Ahimed Hassen. Assessment and utilization practices of feed resources in Basona Worana Woreda of North Shoa. MSc thesis in Haramaya University, Ethiopia; 2006.

10. Mamo Mengesha. Survey on village chicken production under traditional management system in jamma woreda, south wollo. MSC Thesis, Alemaya university, south wollo, Ethiopia; 2006.

11. Lemma Fita, Lemma Abera, NegaTolla, et al. Effect of different Legume Supplements on milk production of Borana Goate. Proceeding of $10^{\text {th }}$ Anwal Conference of Ethiopian Socilty of Animal Production; 2003. p. 21-23.

12. Getachew Eshetie. An assessment of feed resource, their management and impact on livestock productivity Ginch water shed area. MSC Thesis Alemaya University of agriculture, Alemaya; 2004. 171 p.

13. Yestilia admasu. Assessment of livestock feed resources utilization in Alaba Woreda, Southern Ethiopia. CGSpace A Repository of Agricultural Research Outputs. 2008. 127 p. 